\title{
Introduction to the special issue on continental philosophy of law
}

\author{
Nick Smith
}

Published online: 18 February 2009

(C) Springer Science+Business Media B.V. 2009

I should open this volume on Continental Philosophy of Law with a few confessions.

First, I do not find what has traditionally been considered the philosophy of law especially interesting. This is unfortunate given that the most accurate professional description of me-as defined by the American Philosophical Association-is probably "Philosopher of Law." When I think of the field typically referred to as philosophy of law, the analytic jurisprudence of John Austin, H.L.A. Hart, and Lon Fuller comes to mind. I dutifully studied Oliver Wendell Holmes, Karl Llewellyn, and Ronald Dworkin as well, but their ideas never stirred my soul. I feel somewhat more comfortable admitting this now that I am tenured. The prominent practitioners of the school of legal reasoning I found most compelling - Critical Legal Studiesnow describe their own movement as "dead, dead, dead." ${ }^{1}$ So dead, in fact, that my advisors encouraged me to strike all references to the CLS from my vita or risk catching the academic plague that befell it. Richard Posner and his "Law and Economics" movement did light a fire under me, but only because I had never read serious philosophy that I disagreed with so completely.

Perhaps I should consider myself a "Continental Philosopher of Law," but this leads to my second confession. I am not sure what that means. Once I expand my definition of philosophy of law beyond the classics mentioned above, it seems that almost any thinking about law, law-like systems, or even normative concepts can qualify. Brian Leiter, the lead watchdog of philosophy's territories, provides the following sensible advice to graduate students hoping to study in this area:

\footnotetext{
1 Tushnet (2005, p. 99) is summarizing, and largely disagreeing with, Duncan Kennedy about the state of Critical Legal Studies.
}

\footnotetext{
N. Smith (ه)

University of New Hampshire, Durham, NH, USA

e-mail: nick.smith@unh.edu
} 
Topics that fall within philosophy of law include, for example: the nature of law and the relationship between law and morality; the theory of legal reasoning and adjudication; the duty to obey the law; the justification of punishment; the nature of responsibility, moral and legal; theories of liberty and justice; the philosophical foundations of the substantive branches of law (criminal, law, property, torts, contracts, international law, etc.); theories of legislation and legal interpretation; the methodology of legal philosophy; and the intersection between the preceding areas and issues and themes in ethics, political philosophy, philosophy of language, metaphysics, philosophy of action, etc. ${ }^{2}$

I know enough not to try to define continental philosophy, and if you add continental perspectives to the list Leiter provides, then we can appreciate just how wide open this field can seem. If journal editors are gatekeepers, how can one secure a domain with no boundaries?

I also wonder if continental philosophy of law is a generally bad idea. I expressed some reservations regarding a theory of law inspired by the likes of Levinas or Adorno in a recent essay titled "Questions for a Reluctant Jurisprudence of Alterity," which appeared in Desmond Manderson's anthology Essays on Levinas and Law. ${ }^{3}$ Modern law seems antithetical to the sensibilities of many continental philosophers. Law generalizes, reduces, commensurates, and operates in a binary framework of guilt and innocence. It lacks the patience and resources to engage the nuances of concrete particulars. It drifts toward commodification and reproduces essentialism, adversarialism, class structures, and inequality. Continental philosophy of law can therefore seem like a paradox unless conceived as an almost entirely critical undertaking.

Having said that, legal disputes can seem well-suited for reflection on concrete particulars. Whereas political thought tends to consider populations from macrological distances, legal reasoning must tarry with the micrological details of individual cases. Judges must develop the phronesis to mind the infinite particularities of justice because every case invokes the intuitions of reflective judgment rather than the rote application of law to fact. In this respect, theories of alterity might provide a counterbalance to binary determinations that dominate law by imparting much needed humility to considerations of justice. Unlike the adversarial legal system's declarations of guilt or innocence with absolute conviction, movements like ethical phenomenology and negative dialectics foster the anxiety of radical open-mindedness. Certainty becomes the enemy of justice because a lack of humility, facile moralism, inattention to nuance and context, and unwillingness to revise one's beliefs tend toward authoritarianism. This is especially poignant when we contrast the interruptive capacities of theories of alterity with the methodological commitments of the Law and Economics movement, which unflinchingly reduces all human value to an economic metric and provides a powerful example of the totalizing ideology of capitalism digesting the entirety of

\footnotetext{
2 See Leiter (2008).

3 See Manderson (2009).
} 
existence. Perhaps a jurisprudence of alterity could prove compelling, and even useful.

With curiosity and some apprehension, I distributed the following call for papers:

Continental Philosophy Review invites authors to submit papers considering problems in legal theory and the philosophy of law through any of the diverse perspectives associated with contemporary continental philosophy. We welcome papers on a broad range of topics, from examinations of the general nature of law to analyses of particular legal theories, disputes, or opinions.

I received over one hundred submissions. Apparently many very thoughtful people also understand themselves as continental philosophers of law, and I now feel a sense of pride counting myself as a member of this community.

I can think of no better way of describing the field than by reporting on the work of those who self-identify as its practitioners. Given my comments above, I found it interesting that many of the papers avoided discussing law altogether. Notice that only one of the papers included in the volume directly cites case law. When submissions did address law, the tenor was decidedly negative. The crisis of legal authority proved to be the favored topic, with issues of forgiveness, privacy, and human rights also receiving attention from multiple essays. Despite Desmond Manderson having already claimed thirteen papers on Levinas and law for his volume, Levinas provided the inspiration for the greatest number of submissions. Several papers on Derrida's Force of Law surfaced, as did pieces oriented by Arendt, Schmitt, and Agamben.

Each article in this volume includes an abstract, so I will not summarize their contents here. Readers of this journal likely need no introduction to Kelly Oliver and Simon Critchley, two luminaries of contemporary continental philosophy. Unlike the analytic jurisprudence mentioned above, earlier works of Oliver and Critchley led me to believe that philosophy could be both dynamic and practical and steered me toward this profession and away from practicing law. University of Colorado law professor Pierre Schlag may be less familiar to this audience, but if you read only one law review article, I suggest the gonzo jurisprudence-or what he calls "legal surrealism" - of his My Dinner at Langdell's. ${ }^{4}$ I find his essay in this volume more engaging and challenging than any of Derrida's contributions to legal theory on similar problems, and I hope this will refer readers to Schlag's many other truly original writings. Many of his articles deserve close study by continental theorists interested in legal issues, and if more philosophers read Schlag, they might be less influenced by Leiter's claim that "a great deal of what passes for 'philosophy' in law schools-even at some excellent law schools-is sophomoric." 5 Gordon Hull's piece on legal requirements that public libraries install internet filtering programs provides exactly the sort of sophisticated analysis of a

\footnotetext{
4 See Schlag (2004).

5 See Leiter (2008). I could recommend many other texts written by law faculty that should be engaged by more philosophers of law, but for the sake of emphasis I will note only one exceptionally lucid application of continental theories to legal problems: Guyora Binder and Robert Weisberg's Literary Criticisms of Law. (Binder and Weisberg 2000).
} 
current issue that I hoped would materialize for this volume. I look forward to following Hull's career.

I found it immensely gratifying to work with these authors, as they showed exceptional collegiality reading and commenting on each other's papers. I extend my gratitude to each of them for participating in this project. I also thank Robert Scharff and Anthony Steinbock for their vision to create such a volume, and for their willingness to entrust it to me.

\section{References}

Binder, Guyora, and Robert Weisberg. 2000. Literary criticisms of law. Princeton: Princeton University Press.

Leiter, Brian. 2008. The philosophical gourmet report: Advice on choosing graduate programs. http://www.philosophicalgourmet.com/advice.asp.

Manderson, Desmond (ed.). 2009. Essays on Levinas and law: A mosaic. New York: Palgrave Macmillan. Schlag, Pierre. 2004. My dinner at Langdell's. Buffalo Law Review 52: 851-863.

Tushnet, Mark. 2005. Critical legal studies (without modifiers) in the United States. The Journal of Political Philosophy 13(1): 99-112. 